MDPI

sciforum
MOL2NET, International Conference Series on Multidisciplinary Sciences

MODECO-06: Molec. Diversity, Environ. Chem., and

Economy Congress, Paris, France-Ohio, USA, 2021

\title{
Hydrocarbon levels and biochemical biomarkers in the clam Ruditapes decussatus collected from Tunis lagoon (Tunisia)
}

\author{
Chalbia Mansour*, Fadia Ben Taheur, Ridha Mzoughi, Dalila Saidane Mosbahi \\ *E-mail addresses: chalbia27@yahoo.fr
}

University of Monastir, Laboratory of Analysis, Treatment and Valorization of Pollutants of the Environment and Products, Faculty of Pharmacy, IbnSina Street, 5000 Monastir, Tunisia.

\begin{tabular}{|l|l|}
\hline Graphical Abstract & $\begin{array}{l}\text { Abstract } \\
\text { Biomarkers are used as tools to measure physiological, } \\
\text { cellular, biochemical, and/or molecular changes, reflecting } \\
\text { the level of disturbances and alterations caused by the } \\
\text { exposure of organisms to chemical pollutants present in } \\
\text { the environment.In the present study, a multi-biomarker } \\
\text { approach was used to assess the effects of hydrocarbon } \\
\text { contamination in the southern lagoon of Tunis (Tunisia), } \\
\text { on clam Ruditapes decussatus.Sediments and clams were } \\
\text { collected from four locations: three of them were located } \\
\text { within the polluted lagoon (S1, S2 and S3) and another } \\
\text { one was allocated in a clean site on the Mediterranean } \\
\text { coast (SR). Total hydrocarbons were extracted from clam } \\
\text { tissues and sediments.On the other hand, biomarkers of } \\
\text { oxidative stress, neurotoxicity, and lipid peroxidation were } \\
\text { measured.Hydrocarbon analysis revealed a high pollution } \\
\text { state in the south lagoon of Tunis with a spatial } \\
\text { variation.On the other side, our results showed activation } \\
\text { of antioxidant enzymes in clams sampled from the } \\
\text { polluted area as well as neurotoxicity. These results reveal } \\
\text { the alteration of the health status in these organisms } \\
\text { generated by the anthropogenic pollution in this area. } \\
\text { Overall, the present work clearly showed that affected } \\
\text { biomarkers could be useful tools for biomonitoring in the } \\
\text { study area. } \\
\text { Keywords: Biomarkers;Biomonitoring; South lagoon of } \\
\text { Tunis; Ruditapes decussatus; Hydrocarbons. }\end{array}$ \\
\hline
\end{tabular}




\section{Introduction}

Marine bivalves, such as clams, mussels and oysters have been used worldwide as bioindicators to identify chemical pollutants in coastal environments. Indeed, these species are able to accumulate many chemicals in their tissues thanks to their sessile nature and their filter-feeding behaviour (Nasci et al. 1999, Cajaraville et al. 2000, Fournier et al. 2002, Bebianno and Serafim 2003, Sandrini-Neto et al. 2016). However, the concentration of pollutants in tissues alone is not enough to assess the deleterious effects of pollution on animal health (Solé 2000). Thus, biomarkers have been developed to detect and evaluate the effects of exposure to contaminants in the aquatic environment. Furthermore, Romeo et al. 2003(Roméo et al. 2003)underlined the importance of measuring several biomarkers at the same time in the same organisms, to assess health state of marine environment.

Exposure of aquatic organisms to pollutants can induce an increase in the production of reactive oxygen species (ROS) (Coles et al. 1994, Dyrynda et al. 1998, Camus et al. 2002, Chakraborty et al. 2013, Aguirre-Martínez and Martín-Díaz 2020) such as the hydroxyl radical (OH), the superoxide anion radical $\left(\mathrm{O}_{2}{ }^{-}\right)$, the hydrogen peroxide $\left(\mathrm{H}_{2} \mathrm{O}_{2}\right)$ and the singlet oxygen $\left(\mathrm{O}_{2}\right)$. ROS are known as transient species due to their high chemical reactivity and ability to react with DNA, proteins, lipids and carbohydrates in a destructive manner (Storey 1996). To protect against the deleterious effects of ROS, cells contain antioxidant defense mechanisms which include both enzymatic and non-enzymatic components. The antioxidant system involves enzymes such as superoxide dismutase (SOD), catalase (CAT), glutathione peroxidase (GPx), glutathione transferase (GST) and glutathione reductase (GR).

The antioxidant systems can be induced or inhibited under stress conditions. Thereby, the assessment of antioxidant enzymes can provide information on the organism's health status and could be used as a biomarker of pollutant-induced oxidative stress in aquatic organisms (Borković et al. 2008). In recent years, the antioxidant system response has been widely studied and employed as a defense biomarker in aquatic organisms (Regoli et al. 2011).

When these defenses are not sufficient, oxidative stress can cause DNA damage, enzyme inactivation, protein degradation and lipid peroxidation (LPO) (Regoli et al. 2004, Lushchak 2011, Sureda et al. 2011). Furthermore, the measurement of Acetylcholinesterase (AChE) activity is considered a valuable biomarker of exposure to neurotoxic compounds in vertebrate and invertebrate species, such as organophosphates (OPs) and carbamates used in agriculture as pesticides and heavy metals (Akcha et al. 2000, Galgani and Bocquené 2000, Banni et al. 2005).

The aim of the present work was to investigate the hydrocarbon pollution stateof the Southern Lagoon of Tuniscaused by the anthropic activities and to assess his biochemical effectson the carpet shell clam Ruditapesdecussatusan indigenous species of the Mediterranean sea and widely recognized as a good bioindicator in monitoring and ecotoxicological studies (Bebianno et al. 2004). For this reason, Total hydrocarbons $(\mathrm{TH})$ were extracted and aromatic $(\mathrm{AH})$ and non-aromatic (NAH) hydrocarbons fractions were measured in the sediments and the soft tissues of clamscollected from three sites of the Lagoon: the navigation canal, the Rades harbor and the chemical industrial area. Control samples were collected from Louza site considered as a reference site (Banni et al. 2009). In addition,oxidative and neurotoxic status of clams was evaluated through the analysis of catalase, glutathione reductase, superoxide dismutase and acetylcholinesterase activities and malondialdhyde level. 


\section{Material and methods}

\subsection{Sampling sites and sample collection}

The Southern Lagoon of Tunis is a Mediterranean lagoon covers an area of $7 \mathrm{~km}^{2}$ and located in the southwest of the Gulf of Tunis; on the east side of Tunis (Tunisia). This lagoon is separated from North lagoon of Tunis by the navigation canal that connects Radesharbor to the harbors of Tunis and La Goulette(Jouini et al. 2005). This lagoon is adversely affected by industrial contaminants from the industrial zone, substantial harbor activities and the untreated urban sewage from the city of Tunis and its southern suburbs (Jouini et al. 2005). Consequently, high levels of polycyclic aromatic hydrocarbons(Mzoughi and Chouba 2011) and heavy metals have been found in the lagoon sediments and clams(Hellal et al. 2011, Mansour et al. 2020).

Three sampling sites were chosen in the Lagoon of Tunis because they are geographically located near contamination sources and differently influenced by anthropogenic impact. The first sampling site (S1) is the navigation channel that connects the harbor of La Goulette to the harbor of Tunis $\left(10^{\circ} 14^{\prime} 41.6^{\prime \prime} \mathrm{W}, 36^{\circ} 48^{\prime} 15.3^{\prime \prime} \mathrm{N}\right)$ (Fig. 1). The second site (S2) is the Rades harbor $\left(10^{\circ} 16^{\prime} 19.1^{\prime \prime} \mathrm{W}\right.$, $36^{\circ} 48^{\prime} 12.4^{\prime \prime} \mathrm{N}$ ) which is the largest commercial port in Tunis. The third site (S3) is the chemical industrial area $\left(10^{\circ} 16^{\prime} 53.1^{\prime \prime} \mathrm{W}, 36^{\circ} 47^{\prime} 59.6^{\prime \prime} \mathrm{N}\right)$. Control clams were collected from a coastal site at Louza (SR, 35 $02^{\prime} 00.1^{\prime \prime} \mathrm{N} 11^{\circ} 00^{\prime} 66.3^{\prime \prime} \mathrm{E}$ ), which has been considered as a reference site in monitoring programs along the Tunisian coasts (Banni et al. 2009).

Carpet shellclams (Ruditapes decussatus) and sediments were collected in February 2016. Upon arrival to the laboratory, clams were transferred to aquaria filled with aerated sea water collected from each sampling sites for $24 \mathrm{~h}$ (Hurtado et al. 2011)at $13{ }^{\circ} \mathrm{C}$. The next day, for biochemical analysis, the entire soft body of 10 animals was separated and homogenized in TRIS buffer (TRIS $50 \mathrm{mM}, \mathrm{NaCl}$ $150 \mathrm{mM}$, DTT $1 \mathrm{mM}$, protease inhibitor cocktail $\mathrm{pH}$ 7.4) in a $1: 3$ ratio (W:V) using a motor-driven glass-teflon homogenizer at 500rpm. Thehomogenateswerethencentrifugedfor 25 minat $9000 \mathrm{~g}$ at $4^{\circ} \mathrm{C}$ and the resulting supernatants (called S9 fractions) were immediately frozen at $-80^{\circ} \mathrm{C}$ until further use. All measurements were performed at $4{ }^{\circ} \mathrm{C}$ to prevent enzyme or tissue degradation. Each biochemical measurement was carried out on 20 individual clams and each measurement was performed in triplicate.

For the hydrocarbon analysis the soft tissues of clams were extracted, washed in ultrapure water and lyophilized. Likewise, the sediment samples were lyophilized then passed through a stainless steel sieve $(100 \mu \mathrm{m})$. 


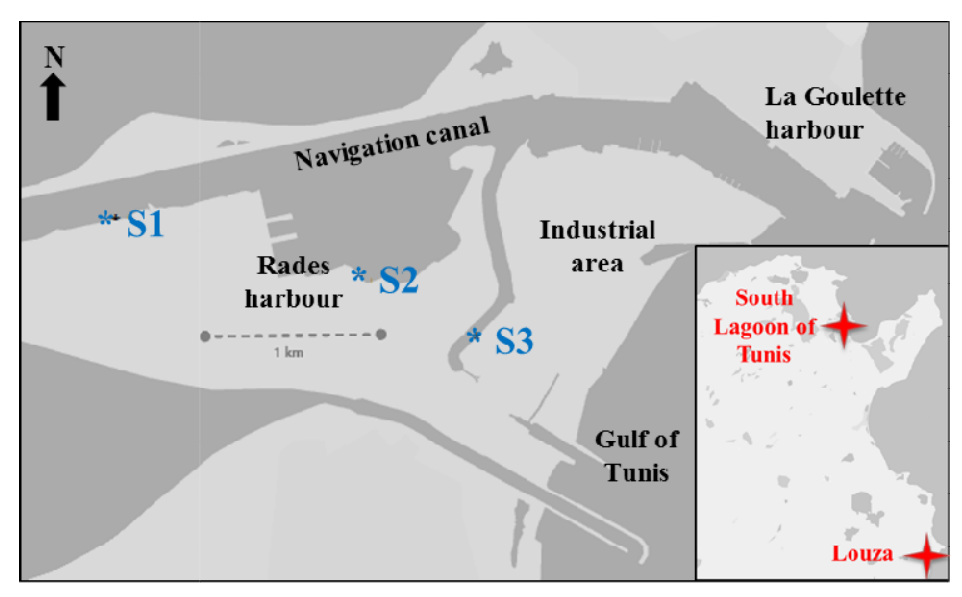

Fig. 1.Map of the study area and location of sampling sites in Tunis lagoon and Louza (Tunisia).

\subsection{Hydrocarbons Analyses}

The extraction of the Total Hydrocarbons $(\mathrm{TH})$ from sediments and clam tissues consists of a liquid / solid extraction following the method ofMansour et al.(Mansour et al. 2020). Briefly, an amount of $50 \mathrm{~g}$ of sediments or $5 \mathrm{~g}$ of clam soft tissues were extracted in a soxhlet extractor for $8 \mathrm{~h}$ with $250 \mathrm{~mL}$ of chloroform at $50{ }^{\circ} \mathrm{C}$ for sediment and with $250 \mathrm{~mL}$ of methanol at $30{ }^{\circ} \mathrm{C}$ for clam tissues. For organic samples, the extraction was followed by hot saponification to allow hydrocarbons liberation from lipids. This step was carried out by adding $20 \mathrm{~mL}$ of $\mathrm{KOH}(0.7 \mathrm{M})$ and $30 \mathrm{~mL}$ of distilled water to the extractfor $2 \mathrm{~h}$. After that, a liquid/liquid extraction was performed 3 times with hexane.Aftercondensation by a rotary evaporator, the extract was purified and separated into aromatic hydrocarbons ( $\mathrm{AH}$ ) and non-aromatic hydrocarbons (aliphatic/ NAH), using liquid chromatography. The stationary phase used was neutral alumina/silica for organisms and silica for sediments. The elution was done by using $5 \mathrm{~mL}$ of $\mathrm{n}$-hexane and $5 \mathrm{~mL}$ of $\mathrm{n}$-hexane/ chloroform $(2: 1, \mathrm{v} / \mathrm{v})$ for $\mathrm{AH}$ and NAH fractions, respectively (Zrafi-Nouira et al. 2008). After evaporation, the AH and NAH fractions were measured and the relative hydrocarbons concentrations in the contaminated sites compared to hydrocarbons concentration in the reference site(SR) were calculated:

Relative hydrocarbonslevel $=[$ hydrocarbons] contaminated site $/$ [hydrocarbons]SR .

\subsection{Biochemical analyses}

\subsubsection{Total protein determination}

Total protein concentration in S9 fractions was determined according to the method of Bradford (Bradford 1976), adapted for microplate reader at $595 \mathrm{~nm}$ using bovine serum albumin (BSA) as a standard.

\subsubsection{Antioxidant defense}

Catalase (CAT) activity was measured based on the method adapted fromAebi(Aebi 1984) slightly modified by Clairbone(Clairbone 1985). CAT activity was determined by measuring the decrease of absorbance at $240 \mathrm{~nm}$ due to the presence of $\mathrm{H}_{2} \mathrm{O}_{2}$ concentration. The enzymatic activity was expressed in $\mu \mathrm{mol}$ of $\mathrm{H}_{2} \mathrm{O}_{2} \mathrm{~min}^{-1} \mathrm{mg}^{-1}$ protein. 
Glutathione reductase(GR) activity was determined during the reduction of oxidised glutathione (GSSG) to GSH, and measured by following the decrease in NADPH levels at $340 \mathrm{mn}$, as described by Pivaet al.(Piva et al. 2011). The enzymatic activity was expressed in nmolmin ${ }^{-1} \mathrm{mg}^{-1}$ protein.

Superoxide dismutase (SOD) activity was determined following the method described by Mc Cord and Fridivich(McCord and Fridovich 1969), by measuring the decrease of absorbance of substrate cytochrome-C through xanthine oxidase/hypoxanthine system, at $550 \mathrm{~nm}$. The enzymatic activity was expressed as Unit $\mathrm{mg}^{-1}$ protein.

\subsubsection{Oxidative damage}

Lipid peroxidation level was measured based on the method adapted from Buege and Aust(Buege and Aust 1978)by estimating the formation of malondialdehyde (MDA)a major decomposition product from lipid peroxidation. Absorbance was measured at $530 \mathrm{~nm}$ and lipid peroxidation was expressed as MDA levels in nmolmg ${ }^{-1}$ protein.

\subsubsection{Neurotoxicity}

Acetylcholinesterase (AChE) activity was quantified according to the colorimetric method of Ellmanet al. (Ellman et al. 1961) adapted to microplate reader by Galgani and Bocquené(Galgani and Bocquene 1991). The method measures the absorbance of 5-thio-2-nitrobenzoate (TNB) (yellow) formed by the reaction of thiocholine, a product of acethylcholine (ATC) cleavage by AChE with 5,5dithio-bis-2-nitrobenzoate (DTNB). Absorbance was measured at421 nm and AChE activity is expressed as ATC $\mathrm{min}^{-1} \mathrm{mg}^{-1}$ protein.

\subsection{Statistical analysis}

The results are expressed as mean \pm standard error (SE). Data were statistically analysed by oneway analysis of variance (ANOVA) using Tukey's HSD to identify differences between groups. Statistical analyses were conducted using the software STATISTICA (Statsoft STATISTICA version 6.1.478.0) and differences were considered statistically significant when $p$ values were lower than 0.05. Principal Component Analysis (PCA) was also performed.

\section{Results and Discussion}

In this field study, we measured a battery of biochemical biomarkers in the carpet shell clam Ruditapes decussatustissues collected from the South Lagoon of Tunis, which is influenced by the contribution of a wide variety of pollutants. CAT, GR, SOD, MDA and AChEactivities were measured in the tissues of clams collected during February 2016. In the other hand, total hydrocarbons were extracted from clam tissues and sediments and fractionated into aromatic hydrocarbons (AH) and nonaromatic hydrocarbons (NAH).

\subsection{Hydrocarbon analyses}

The results of relative hydrocarbon levels in clam tissues and sediments are reported in Figure 2 and Figure 3, respectively. 
The results of petroleum hydrocarbon ( $\mathrm{AH}$ and $\mathrm{NAH}$ ) contents in clams tissues revealed higher levels in clams from contaminated sites than control clams(site of Louza). Moreover, spatial variation of hydrocarbon concentrations was observed among the three sampling sites. The AH level was higher in clams from S1 $\left(3.480 \pm 0.317 \mu \mathrm{g} \mathrm{mg}^{-1}\right.$ dry weight $)$ and $\mathrm{S} 3\left(3.853 \pm 0.288 \mu \mathrm{g} \mathrm{mg}^{-1}\right.$ dry weight $)$ compared to the control site SR $\left(0.492 \pm 0.230 \mu \mathrm{g} \mathrm{mg}^{-1}\right.$ dry weight $)$ with significant difference in clams collected at S1 and S2 (Fig. 2A). The relativeAH level revealed 7.07- and 7.83-fold increase in S1 and S3 respectively, compared to site SR. Similarly, NAH concentration was significantly higher in clams collected at $\mathrm{S} 1\left(5.180 \pm 0.259 \mu \mathrm{g} \mathrm{mg}^{-1}\right.$ dry weight $)$ and $\mathrm{S} 3\left(4.857 \pm 0.440 \mu \mathrm{g} \mathrm{m}^{-1}\right.$ dry weight $)$ compared to the control site SR $\left(0.827 \pm 0.199 \mu \mathrm{g} \mathrm{mg}^{-1}\right.$ dry weight), with 6.26- and 5.87-fold increase, respectively (Fig. 2B).

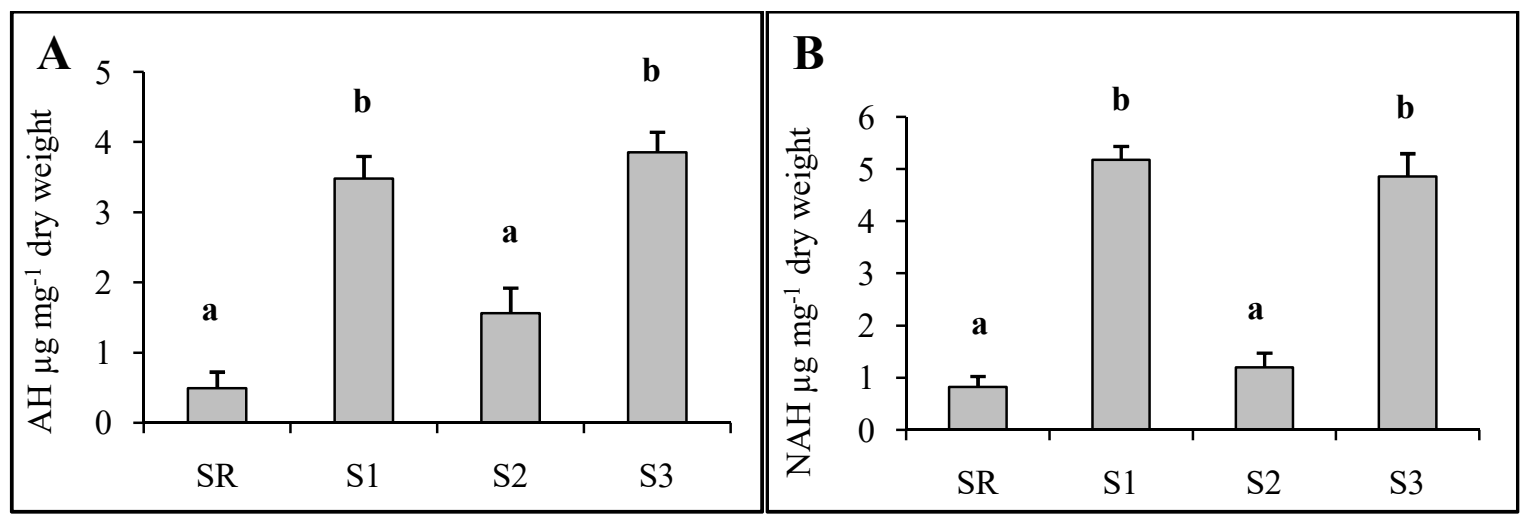

Fig.2.Concentrations of (A) aromatic (AH) and (B) non aromatic (NAH) hydrocarbons ( $\mu \mathrm{g} / \mathrm{mg}$ dry weight) in the soft tissue of clam Ruditapes decussatus collected from three sites of the lagoon (S1, S2 and S3) and the control site (SR). The bars represent the mean \pm SE. Data with different superscript expressed significant differences between sites $(\mathrm{p}<0.05$, Tukey test).

Similarly, sediment samples from contaminated site showed higher hydrocarbon levels than control site with spatial variation among the sampling sites. The AH level was significantly higher in the three site of the lagoon S1 $\left(0.038 \pm 0.004 \mu \mathrm{g} \mathrm{mg}^{-1}\right.$ dry weight $), \mathrm{S} 2\left(0.066 \pm 0.005 \mu \mathrm{g} \mathrm{mg}^{-1}\right.$ dry weight $)$ and S3 $\left(0.076 \pm 0.005 \mu \mathrm{g} \mathrm{mg}^{-1}\right.$ dry weight $)$ compared to control site SR $\left(0.008 \pm 0.002 \mu \mathrm{g} \mathrm{mg}^{-1}\right.$ dry weight)with 4.75-, 8.25- and 9.50-fold increase, respectively (Fig. 3A). Similarly, NAH concentration was significantly higher in the three site of the lagoon (Fig. 3B) while, the maximum value was observed in $\mathrm{S} 1\left(0.488 \pm 0.008 \mu \mathrm{g} \mathrm{mg}^{-1}\right.$ dry weight $)$ compared to the control site $\left(0.010 \pm 0.002 \mu \mathrm{g} \mathrm{mg}^{-1}\right.$ dry weight) with 48.80 - fold increase.

In the present study, the results of the quantitative study showed enrichment in AH and NAH in both matrixes (sediments and clams) collected from the three sites of the South Lagoon of Tunis (S1, S2 and S3) compared to the reference site (SR). This enrichment is probably due to the shipping traffic and the urban and industrial discharges into the lagoon. These results are in agreement with previous studies which revealed a contamination of clams and sediments in the navigation channel of Tunis lagoon by petroleum hydrocarbons (Khedir-Ghenim et al. 2009, Chalghmi et al. 2016). The results of the present study confirm contamination of the Tunis lagoon by petroleum hydrocarbons (aromatic and non aromatic).

In this study, the highest levels of $\mathrm{AH}$ in clams and sediments were recorded at site S3, which may be due to the presence of several petrochemical industries in this area. 


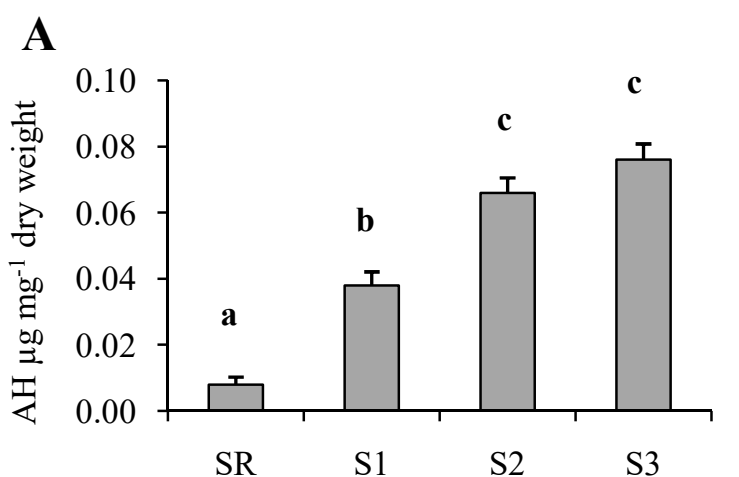

B

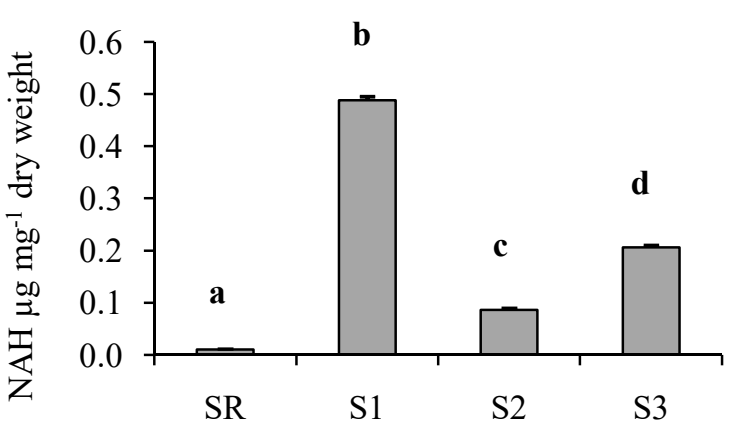

Fig.3.Concentrations of (A) aromatic (AH) and (B) non aromatic (NAH) hydrocarbons ( $\mu \mathrm{g} / \mathrm{mg}$ dry weight) in the surface sediments sampled from three sites of the lagoon (S1, S2 and S3) and the control site (SR). The bars represent the mean \pm SE. Data with different superscript expressed significant differences between sites $(\mathrm{p}<0.05$, Tukey test).

\subsection{Antioxidant defense}

The variations of the antioxidant defense enzyme CAT, SOD and GR in R.decussatus sampled at the four sites are shown in Figure4.

The CAT activity (Fig. 4A) was overall significantly higher in clams sampled from the three sites of Tunis lagoon (S1, S2 and S3) than the reference site $(\mathrm{p}<0.05)$. Organisms sampled from site S1 showed thehighest CAT activity (123.9 $\pm 7.71 \mu \mathrm{mol} \mathrm{min}^{-1} \mathrm{mg}^{-1}$ protein) compared to those from the other sites. A similar pattern of induced CAT activity was observed in previous studies carried out on the same species collected from Tunis lagoon (Banni et al. 2003, Chalghmi et al. 2016, Chalghmi et al. 2016).Increase in CAT activity means oxidative stress, often related to excessive ROSproduction during the catabolism of various organic compounds(Clairbone 1985).Indeed, an increase of ROS generation was recorded aquatic organisms exposed to several contaminants (Coles et al. 1994, Dyrynda et al. 1998, Camus et al. 2002, Chakraborty et al. 2013). Thus, our results can be explained by an increase in ROS production owing to the presence of organic contaminants in the lagoon.

Glutathione reductase is involved in the removal of hydrogen peroxide and in the conversion of oxidized glutathione (GSSG) to the reduced form (GSH). In the current study, Gr activity (Fig. 4C) was significantly higher in clams sampled from sites S1, S2 and S3 than the site SR $(\mathrm{p}<0.05)$. Organisms sampled from site S1 showed the highest GR activity $\left(121.19 \pm 8.60 \mu \mathrm{mol} \mathrm{min} \mathrm{mg}^{-1}\right.$ protein) compared to those from the other sites $(72.79 \pm 3.89,107.82 \pm 3.89$ and $116.61 \pm 12.41 \mathrm{nmol}$ $\mathrm{min}^{-1} \mathrm{mg}^{-1}$ prot, in SR, S2 and S3 respectively). Similar findings have been reported in the digestive glands of the fan mussel Pinna nobilis collected from Ibiza Island (Western Mediterranean) after the Don Pedro spillage (Capó et al. 2015) and the mangrove oyster Crassostreabrasiliana exposed for sublethal concentrations of diesel fuel water-accommodated fraction (Lüchmann et al. 2011). Moreover, an increase of GR concentration was recorded in the digestive glands of R.decussatus transplanted to a pesticides contaminated site in the Mar Menor lagoon (Spain) (Campillo et al. 2013). In the present study, increased Gr activity in R. decussatus collected from the lagoon are in accordance with the results of CAT activity, indicating oxidative stress in the clams harvested from the south lagoon of Tunis. 
The Variation of SOD activity has been widely used as a useful biomarker to assess susceptibility of organisms to oxidative stress. In the current investigation, SOD activity (Fig. 4B) was significantly higher in clams sampled from S1 (119.15 $\pm 9.52 \mathrm{U} \mathrm{SOD} \mathrm{mg}^{-1}$ protein) than SR $\left(70.38 \pm 4.91 \mathrm{U} \mathrm{SOD} \mathrm{mg}^{-}\right.$ 1 protein). These results suggest that animals from S1 had a higher efficiency to cope with oxidative stress than bivalves from S2 and S3. Matozzoet al.(Matozzo et al. 2012) explained such reduction in antioxidant enzyme activities in clam $R$. philippinarum by the exposure of clams to both natural and anthropogenic factors capable to affect antioxidant enzymes. The low level found at S2 and S3 might be explained by the compensatory or adaptativeantioxidative responses. This hypothesis is supported by the high CAT and Gr activities described previously at S2 and S3.

\subsection{Oxidative damage}

MDA level is an indicator of lipid peroxidation which has been widely used as an indicator of oxidative damages to membranes and, therefore, of oxidative stress (Banni et al. 2009, Ahmad et al. 2011). Several environmental contaminants such as heavy metals and hydrocarbons have been reported to increase MDA concentration. Capo et al. (Capó et al. 2015) highlighted an increase of MDA concentration in the digestive gland of the bivalve Pinna nobilis one month after Don Pedro oil spillage. A study performed on the clam, Ruditapesphilippinarumshowed a lowerlipid peroxidation in animal exposed for 14 days toareas near wastewater treatment plant effluent discharges in the Bay of Cádiz (Spain) (Aguirre-Martínez and Martín-Díaz 2020).In this field study, no significant difference in MDA level was observed between polluted and clean sites despite the high antioxidant enzyme activities recorded in the polluted area (Fig. 4D). A possible explanation for this is that the intensity of oxidative stress necessary to trigger a lipid peroxidation requires a different threshold of contamination.

\subsection{Neurotoxicity biomarkers}

The inhibition of AChE activity was frequentlyused as specific biomarkers to indicate the presence of neurotoxic compounds such as organophosphates (OPs) and carbamates used in agriculture as pesticides and heavy metals(Akcha et al. 2000, Galgani and Bocquené 2000, Banni et al. 2005).In the present study, AChE activity (Fig. 4E) was significantly lower in clams sampled from S1 $(8.27 \pm 0.4$ nmol min $\mathrm{mg}^{-1}$ protein) than SR (13.28 $\pm 1.41 \mathrm{nmol} \mathrm{min}^{-1} \mathrm{mg}^{-1}$ protein). A similar inhibition of AChE activity was recorded in the same clam specie Ruditapes decussates harvested from the Lagoon of Bizerte (Tunisia) (Dellali 2001, Banni et al. 2003) which is continuously submitted to insect management and highly influenced by TinjaOued contaminated by drained pesticides from neighbouring agricultural areas (Dellali 2001). In the same way, an inhibition of AChE activity was reported in clams Ruditapes philippinarum collected from seaward and landward sites in the Lagoon of Venice (Matozzo et al. 2010, Matozzo et al. 2012). Moreover, AChE activity has been found to be modulated by other contaminants environmental such as heavy metals and hydrocarbons. For example, an inhibition of AChE activity was reported in mussels Mytilusgalloprovincialis after exposure to B(a)P (Akcha et al. 2000, Banni et al. 2010). Moreover, an inhibition of AChE activity was reported in the clam, Ruditapes philippinarum by exposing the animals to wastewater treatment plant effluent discharges in the Bay of Cádiz (Spain) (Aguirre-Martínez and Martín-Díaz 2020).The results of the present study and those available in the literature suggest a possible exposure of clams collected from the site $\mathrm{S} 1$ to neurotoxic compounds. 


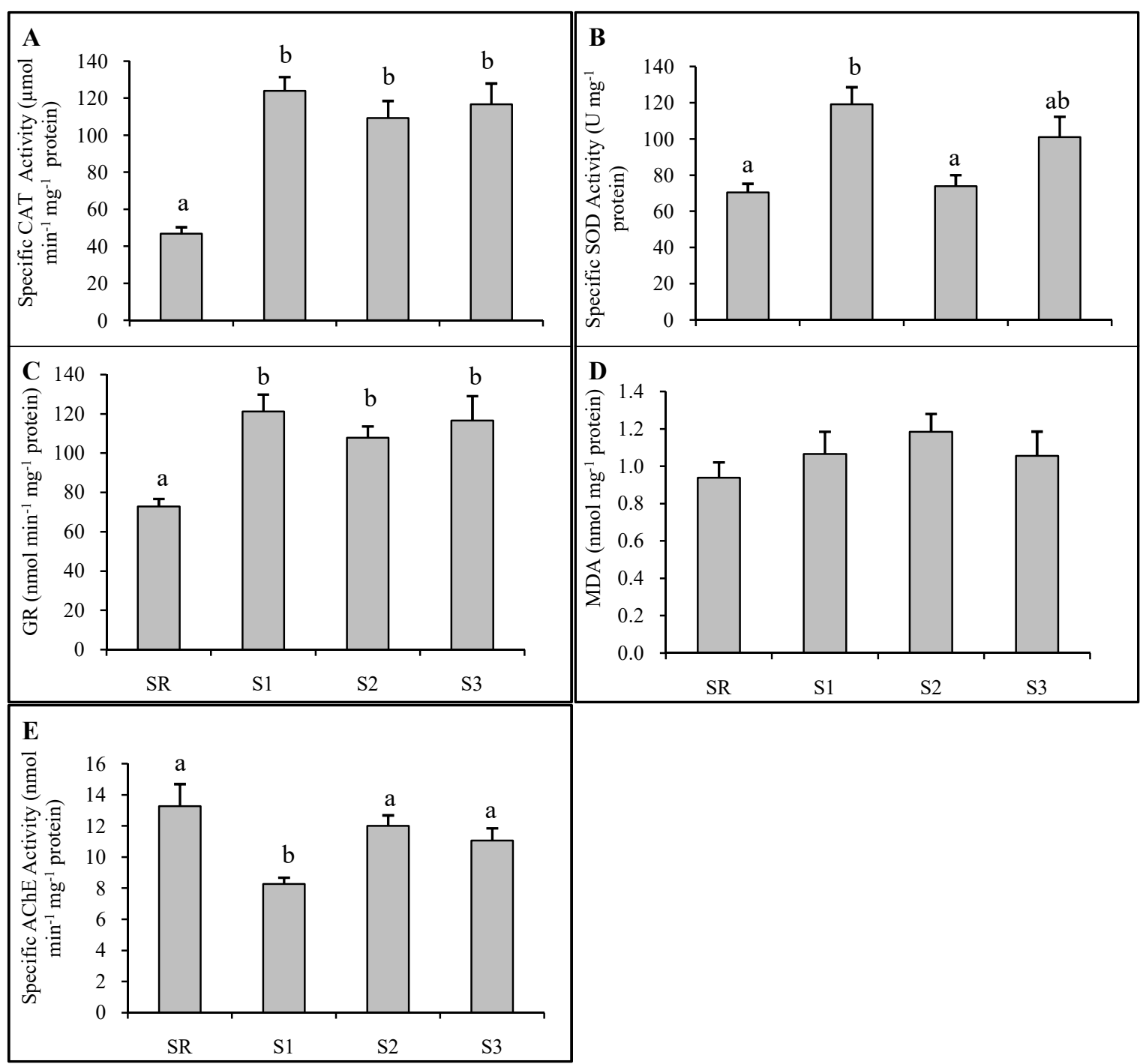

Fig. 4. Catalase (A), Superoxide dismutase (B), Glutathione reductase (C), Acetylchlinesterase (E) activities and Malondialdehyde concentration (D) in clam Ruditapes decussatus collected from three sites of the lagoon (S1, S2 and S3) and the control site (SR). The bars represent the mean $\pm \mathrm{SE}$. Small letters denote significant differences between sites (ANOVA, $p<0.05$ ).

\subsection{Principal component analysis}

Principal component analysis (PCA) was performed to obtain an overview of the spatial distribution of the biochemical biomarker and hydrocarbon levels data. Two principal components were extracted which accounted for $74.37 \%$ of the total variance (Fig.5): PC1 explained $54.37 \%$ of the total variance was positively loaded by biochemical parameters (CAT, GR, SOD, MDA and AChE) in clams and hydrocarbon levels in both matrix sediment (S-AH and S-NAH) and clams (O-AH and ONAH). PC2 explained $20.00 \%$ of the total variance. According to PC2 axis, the three sites S1,S2 and S3 were clearly discriminated from the control site SR. 


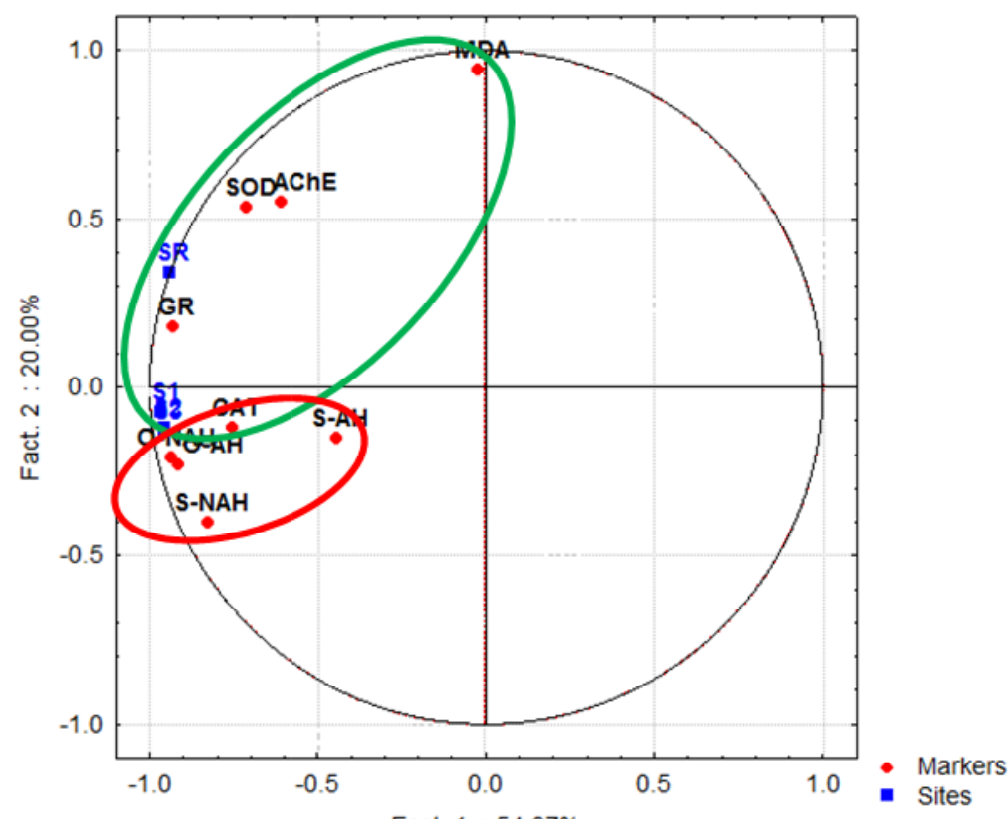

Fig.5. Results of PCA of the two main factors produced by Hydrocarbon levels (O-AH, O-NAH, SAH and S-NAH) and biomarkers (AChE, CAT, GR, MDA and SOD) in clams, Ruditapes decussatus, collected from the three sites of the southern lagoon of Tunis (S1, S2 and S3) and the control site (SR).

Pearson's correlation coefficients between the studied parameters are shown in Table 1.A correlation coefficient higher than 0.5 was considered as significant at $\mathrm{P}<0.05$. In our experimental conditions, AChE activity was positively correlated withGR activity $(\mathrm{r}=0.701)$ and SOD activity $(\mathrm{r}=$ $0.552)$ which was also positively correlated withCAT activity $(\mathrm{r}=0.531) \mathrm{GR}$ activity $(\mathrm{r}=0.756)$ and O-NAH $(\mathrm{r}=0.567)$. Moreover, CAT activitywas positively correlated withGR activity $(\mathrm{r}=0.604)$ and hydrocarbon levels $(0.667,0.606,0.541$ and 0.596 for O-AH, O-NAH, S-AH and S-NAH, respectively). Furthermore, O-AH level was positively correlated with O-NAH $(r=0.922), \mathrm{S}-\mathrm{AH}(\mathrm{r}=$ $0.573)$ and S-NAH $(r=0.761)$.

Table 1.Pearson's correlation coefficients (r) of hydrocarbon levels and biomarkers.

\begin{tabular}{llllllllll}
\hline & AChE & SOD & MDA & CAT & GR & O-AH & O-NAH & S-AH & S-NAH \\
\hline AChE & 1 & & & & & & & & \\
SOD & $\mathbf{0 . 5 5 2}$ & 1 & & & & & & & \\
MDA & 0.430 & 0.480 & 1 & & & & & & \\
CAT & 0.131 & $\mathbf{0 . 5 3 1}$ & 0.047 & 1 & & & & & \\
GR & $\mathbf{0 . 7 0 1}$ & $\mathbf{0 . 7 5 6}$ & 0.125 & $\mathbf{0 . 6 0 4}$ & 1 & & & & \\
O-AH & 0.462 & 0.475 & -0.168 & $\mathbf{0 . 6 6 7}$ & $\mathbf{0 . 7 5 4}$ & 1 & & & \\
O-NAH & 0.474 & $\mathbf{0 . 5 6 7}$ & -0.194 & $\mathbf{0 . 6 0 6}$ & $\mathbf{0 . 8 1 6}$ & $\mathbf{0 . 9 2 2}$ & 1 & & \\
S-AH & 0.200 & 0.003 & 0.030 & $\mathbf{0 . 5 4 1}$ & 0.296 & $\mathbf{0 . 5 7 3}$ & 0.325 & 1 & \\
S-NAH & 0.327 & 0.426 & -0.428 & $\mathbf{0 . 5 9 6}$ & $\mathbf{0 . 7 4 7}$ & $\mathbf{0 . 7 6 1}$ & $\mathbf{0 . 8 9 2}$ & 0.118 & 1 \\
\hline
\end{tabular}

\section{Conclusion}

Hydrocarbon analysis revealed a high pollution state in the south lagoon of Tunis.On the other side, our results reveal activation of antioxidant enzymes in clams sampled from the polluted area as well as neurotoxicity. These results demonstrate the alteration of the health status in these organisms 
generated by high pollution by petroleum hydrocarbons in all sampling sites in the south lagoon of Tunis. Overall, the current study reveals the efficiency of this methodological approach to evaluate physiological responses in Ruditapes decussatus to environmental disruption caused by anthropogenic pollution and reinforces the idea that the biomarker approach can be considered complementary to the chemical characterization of sampling site.

\section{Acknowledgements}

This study was supported by the Ministry of Scientific Research and Technology, the University of Monastir,Tunisia.

\section{References}

Aebi, H. (1984) [13] Catalase in vitro. Methods in enzymology 105, 121-126.

Aguirre-Martínez, G. and Martín-Díaz, M. (2020) A multibiomarker approach to assess toxic effects of wastewater treatment plant effluents and activated defence mechanisms in marine (Ruditapes philippinarum) and fresh water (Corbicula fluminea) bivalve species. Ecotoxicology 29, 941958.

Ahmad, I., Coelho, J.P., Mohmood, I., Pacheco, M., Santos, M.A., Duarte, A.C. and Pereira, E. (2011) Immunosuppression in the infaunal bivalve Scrobicularia plana environmentally exposed to mercury and association with its accumulation. Chemosphere 82, 1541-1546.

Akcha, F., Izuel, C., Venier, P., Budzinski, H., Burgeot, T. and Narbonne, J. (2000) Enzymatic biomarker measurement and study of DNA adduct formation in benzo [a] pyrene-contaminated mussels, Mytilus galloprovincialis. Aquat. Toxicol. 49, 269-287.

Banni, M., Ben Dhiab, R., El Abed, A. and Boussetta, H. (2003) Genotoxicity, catalase, and acetylcholinesterase in the assessment of the pollution status of some sites on the Tunisian littoral. Bulletin of environmental contamination and toxicology 70, 0854-0860.

Banni, M., Bouraoui, Z., Ghedira, J., Clearandeau, C., Jebali, J. and Boussetta, H. (2009) Seasonal variation of oxidative stress biomarkers in clams Ruditapes decussatus sampled from Tunisian coastal areas. Environ. Monit. Assess. 155, 119-128.

Banni, M., Jebali, J., Daubeze, M., Clerandau, C., Guerbej, H., Narbonne, J. and Boussetta, H. (2005) Monitoring pollution in Tunisian coasts: application of a classification scale based on biochemical markers. Biomarkers 10, 105-116.

Banni, M., Negri, A., Dagnino, A., Jebali, J., Ameur, S. and Boussetta, H. (2010) Acute effects of benzo [a] pyrene on digestive gland enzymatic biomarkers and DNA damage on mussel Mytilus galloprovincialis. Ecotoxicology and Environmental Safety 73, 842-848.

Bebianno, M., Geret, F., Hoarau, P., Serafim, M., Coelho, M., Gnassia-Barelli, M. and Romeo, M. (2004) Biomarkers in Ruditapes decussatus: a potential bioindicator species. Biomarkers 9, 305-330.

Bebianno, M.J. and Serafim, M.A. (2003) Variation of Metal and Metallothionein Concentrations in a Natural Population of Ruditapes decussatus. Arch. Environ. Contam. Toxicol. 44, 0053-0066.

Borković, S.S., Pavlović, S.Z., Kovačević, T.B., Štajn, A.Š., Petrović, V.M. and Saičić, Z.S. (2008) Antioxidant defence enzyme activities in hepatopancreas, gills and muscle of Spiny cheek crayfish (Orconectes limosus) from the River Danube. Comparative Biochemistry and Physiology Part C: Toxicology \& Pharmacology 147, 122-128. 
Bradford, M.M. (1976) A rapid and sensitive method for the quantitation of microgram quantities of protein utilizing the principle of protein-dye binding. Analytical biochemistry 72, 248-254.

Buege, J.A. and Aust, S.D. (1978) [30] Microsomal lipid peroxidation. Methods in enzymology 52, 302-310.

Cajaraville, M.P., Bebianno, M.J., Blasco, J., Porte, C., Sarasquete, C. and Viarengo, A. (2000) The use of biomarkers to assess the impact of pollution in coastal environments of the Iberian Peninsula: a practical approach. Sci. Total. Environ. 247, 295-311.

Campillo, J.A., Albentosa, M., Valdés, N.J., Moreno-González, R. and León, V.M. (2013) Impact assessment of agricultural inputs into a Mediterranean coastal lagoon (Mar Menor, SE Spain) on transplanted clams (Ruditapes decussatus) by biochemical and physiological responses. Aquat. toxicol. 142, 365-379.

Camus, L., Jones, M., Børseth, J., Grøsvik, B., Regoli, F. and Depledge, M. (2002) Total oxyradical scavenging capacity and cell membrane stability of haemocytes of the Arctic scallop, Chlamys islandicus, following benzo (a) pyrene exposure. Mar. Environ. Res. 54, 425-430.

Capó, X., Tejada, S., Box, A., Deudero, S. and Sureda, A. (2015) Oxidative status assessment of the endemic bivalve Pinna nobilis affected by the oil spill from the sinking of the Don Pedro. Mar. Environ. Res. 110, 19-24.

Chakraborty, S., Ray, M. and Ray, S. (2013) Cell to organ: Physiological, immunotoxic and oxidative stress responses of Lamellidens marginalis to inorganic arsenite. Ecotoxicol. Environ. Saf. 94, 153-163.

Chalghmi, H., Bourdineaud, J.P., Haouas, Z., Gourves, P.Y., Zrafi, I. and Saidane-Mosbahi, D. (2016) Transcriptomic, Biochemical, and Histopathological Responses of the Clam Ruditapes decussatus from a Metal-Contaminated Tunis Lagoon. Archives of environmental contamination and toxicology 70, 241-256.

Chalghmi, H., Zrafi, I., Gourves, P.Y., Bourdineaud, J.P. and Saidane-Mosbahi, D. (2016) Combined effects of metal contamination and abiotic parameters on biomarker responses in clam Ruditapes decussatus gills: an integrated approach in biomonitoring of Tunis lagoon. Environmental Science: Processes \& Impacts 18, 895-907.

Chalghmi, H., Zrafi, I. and Saidane-Mosbahi, D. (2016) Chronic Effects of Petroleum Hydrocarbons in Tunis-Navigation Channel On Phase I and II Biotransformation Enzymes in Bivalve Species. Int. J. Res. Chem. Environ. 6, 28-33.

Clairbone, A. (1985). Catalase activity. Handbook of methods for oxygen radical research, CRC Press, Boca Raton Florida (1985).

Coles, J.A., Farley, S.R. and Pipe, R.K. (1994) Effects of fluoranthene on the immunocompetence of the common marine mussel, Mytilus edulis. Aquat. Toxicol. 30, 367-379.

Dellali, M. (2001). Utilisation de la gluthathion-S-transferase dans la biosurveillance de la lagune de Bizerte. Colloque PRICAT/RIGEDMER.

Dyrynda, E.A., Pipe, R.K., Burt, G.R. and Ratcliffe, N.A. (1998) Modulations in the immune defences of mussels (Mytilus edulis) from contaminated sites in the UK. Aquat. Toxicol. 42, 169-185.

Ellman, G.L., Courtney, K.D., Andres, V. and Featherstone, R.M. (1961) A new and rapid colorimetric determination of acetylcholinesterase activity. Biochemical pharmacology 7, 88IN191-9095.

Fournier, M., Pellerin, J., Lebeuf, M., Brousseau, P., Morin, Y. and Cyr, D. (2002) Effects of exposure of Mya arenaria and Mactromeris polynyma to contaminated marine sediments on phagocytic activity of hemocytes. Aquat. Toxicol. 59, 83-92. 
Galgani, F. and Bocquene, G. (1991) Semi-automated colorimetric and enzymatic assays for aquatic organisms using microplate readers. Water Research 25, 147-150.

Galgani, F. and Bocquené, G. (2000) Molecular biomarkers of exposure of marine organisms to organophosphorus pesticides and carbamates. Use of Biomarkers for Environmental Quality Assessment. Elsevier Science Publisher, 113-137.

Hellal, M.E.A., Hellal, F., El Khemissi, Z., Jebali, R. and Dachraoui, M. (2011) Trace metals in algae and sediments from the north-eastern Tunisian lagoons. Bull. Environ. Cont. Toxicol. 86, 194198.

Hurtado, M.Á., Da Silva, P.M., Le Goïc, N., Palacios, E. and Soudant, P. (2011) Effect of acclimatization on hemocyte functional characteristics of the Pacific oyster (Crassostrea gigas) and carpet shell clam (Ruditapes decussatus). Fish \& shellfish immunology 31, 978-984.

Jouini, Z., Charrada, R.B. and Moussa, M. (2005) Caractéristiques du Lac Sud de Tunis après sa restauration. Mar. Life 15, 3-11.

Khedir-Ghenim, Z., Zrafi-Nouira, I., Bahri, R., Belayouni, H., Hammami, M., Rouabhia, M. and Saidane-Mosbahi, D. (2009) Identification and distribution of petroleum hydrocarbons in sediments, seawater and Ruditapes decussatus collected from a Mediterranean Sea site. International Journal of Water 5, 35-50.

Lüchmann, K.H., Mattos, J.J., Siebert, M.N., Granucci, N., Dorrington, T.S., Bícego, M.C., Taniguchi, S., Sasaki, S.T., Daura-Jorge, F.G. and Bainy, A.C. (2011) Biochemical biomarkers and hydrocarbons concentrations in the mangrove oyster Crassostrea brasiliana following exposure to diesel fuel water-accommodated fraction. Aquatic toxicology 105, 652-660.

Lushchak, V.I. (2011) Environmentally induced oxidative stress in aquatic animals. Aquat. Toxicol. 101, 13-30.

Mansour, C., Guibbolini, M., Hacene, O.R., Mosbahi, D.S. and Faverney, C.R.-d. (2020) Oxidative Stress and Damage Biomarkers in Clam Ruditapes decussatus Exposed to a Polluted Site: The Reliable Biomonitoring Tools in Hot and Cold Seasons. Archives of Environmental Contamination and Toxicology, 1-17.

Mansour, C., Taheur, F.B., Omrani, R. and Mosbahi, D.S. (2020) Immune biomarker and hydrocarbon concentrations in carpet shell clams (Ruditapes decussatus) collected from a Mediterranean coastal lagoon. Euro-Mediterranean Journal for Environmental Integration 5, 1-9.

Matozzo, V., Binelli, A., Parolini, M., Locatello, L. and Marin, M.G. (2010) Biomarker responses and contamination levels in the clam Ruditapes philippinarum for biomonitoring the Lagoon of Venice (Italy). J. Environ. Monit. 12, 776-786.

Matozzo, V., Binelli, A., Parolini, M., Previato, M., Masiero, L., Finos, L., Bressan, M. and Marin, M.G. (2012) Biomarker responses in the clam Ruditapes philippinarum and contamination levels in sediments from seaward and landward sites in the Lagoon of Venice. Ecol. Indic. 19, 191-205.

McCord, J.M. and Fridovich, I. (1969) Superoxide dismutase an enzymic function for erythrocuprein (hemocuprein). Journal of Biological chemistry 244, 6049-6055.

Mzoughi, N. and Chouba, L. (2011) Distribution of trace metals, aliphatic hydrocarbons and polycyclic aromatic hydrocarbons in sediment cores from the Sicily Channel and the Gulf of Tunis (south-western Mediterranean Sea). Environ. Tec. 32, 43-54.

Nasci, C., Da Ros, L., Campesan, G., Van Vleet, E.S., Salizzato, M., Sperni, L. and Pavoni, B. (1999) Clam Transplantation and Stress-Related Biomarkers as Useful Tools for Assessing Water Quality in Coastal Environments. Mar. Pollut. Bull. 39, 255-260. 
Piva, F., Ciaprini, F., Onorati, F., Benedetti, M., Fattorini, D., Ausili, A. and Regoli, F. (2011) Assessing sediment hazard through a weight of evidence approach with bioindicator organisms: a practical model to elaborate data from sediment chemistry, bioavailability, biomarkers and ecotoxicological bioassays. Chemosphere 83, 475-485.

Regoli, F., Benedetti, M. and Giuliani, M.E. (2011) Antioxidant defenses and acquisition of tolerance to chemical stress. Tolerance to Environmental Contaminants. CRC Press, Boca Raton, FL, 153-173.

Regoli, F., Frenzilli, G., Bocchetti, R., Annarumma, F., Scarcelli, V., Fattorini, D. and Nigro, M. (2004) Time-course variations of oxyradical metabolism, DNA integrity and lysosomal stability in mussels, Mytilus galloprovincialis, during a field translocation experiment. Aquatic toxicology 68, 167-178.

Roméo, M., Hoarau, P., Garello, G., Gnassia-Barelli, M. and Girard, J.P. (2003) Mussel transplantation and biomarkers as useful tools for assessing water quality in the NW Mediterranean. Environmental Pollution 122, 369-378.

Sandrini-Neto, L., Pereira, L., Martins, C.C., de Assis, H.C.S., Camus, L. and Lana, P.C. (2016) Antioxidant responses in estuarine invertebrates exposed to repeated oil spills: Effects of frequency and dosage in a field manipulative experiment. Aquatic Toxicology 177, 237-249.

Solé, M. (2000) Assessment of the results of chemical analyses combined with the biological effects of organic pollution on mussels. TrAC Trends in Analytical Chemistry 19, 1-9.

Storey, K.B. (1996) Oxidative stress: animal adaptations in nature. Brazilian Journal of Medical and Biological Research 29, 1715-1733.

Sureda, A., Box, A., Tejada, S., Blanco, A., Caixach, J. and Deudero, S. (2011) Biochemical responses of Mytilus galloprovincialis as biomarkers of acute environmental pollution caused by the Don Pedro oil spill (Eivissa Island, Spain). Aquatic Toxicology 101, 540-549.

Zrafi-Nouira, I., Khedir-Ghenim, Z., Zrafi, F., Bahri, R., Cheraeif, I., Rouabhia, M. and SaidaneMosbahi, D. (2008) Hydrocarbon pollution in the sediment from the Jarzouna-Bizerte coastal area of Tunisia (Mediterranean Sea). Bulletin of environmental contamination and toxicology $80,566-572$. 